\title{
Process driven patient tracks in FAM
}

\author{
Michael Hansen-Nord ${ }^{1 *}$, Jens Peter Steensen², Søren Holm³ \\ From Danish Society for Emergency Medicine: Research Symposium 2010 \\ Roskilde, Denmark. 20-21 May 2010
}

\section{Background}

The Danish hospital reform requires that in future all acute patients be admitted to one common emergency ward (FAM) at hospitals specially designated for receiving them. At these hospitals they will undergo instant treatment irrespective of time of admittance 24/7/365.

The challenges the designated acute hospitals face is how to plan the FAM in respect to both medical and physical resources, so that instant initial treatment 24/7/ 365 can be effected, and subsequently determine all the consequences for the rest of the wards.

\section{Methods}

The method we have used in solving this problem is through use of process driven patient tracks and simulation. In consultation with the specialist wards, we have obtained consensus on six process driven patient tracks that are expected to cover all types of acute patients. For each track we start by determine the medical processes the patient has to go through. Next the necessary types of medical staff and physical resources for each of the medical processes are determined, together with the estimated process time. It is during the initial common process, the visitation/triage, that it is determined which of the six tracks the acute patient falls under.

\section{Results}

Using the simulation program Flexsim(TM) we are able to quantify the interactions between patients, medical staff and physical facilities hourly during 0-24, given the forecasted future number of acute patients, distributed according to the six patient tracks and their expected hourly 0-24 admittance. Using simulation we can detect and eliminate bottlenecks in an iterative way, and we are consequently able to dimension FAM in regard to

\footnotetext{
* Correspondence: mh-n@dadlnet.dk

'Department of Acute Admissions (AMA), Odense University Hospital, Denmark

Full list of author information is available at the end of the article
}

both staff and physical requirements. In doing this we have taken into consideration the average time we will allow an acute patient to remain in FAM, including waiting time. This time limit has a major impact on the actual choice of processes and the overall dimensioning of FAM, as well as on the number of the various types of medical and auxiliary staff required to be present hourly $0-24$.

\section{Conclusion}

Introducing process driven patient tracks and using simulation will prove to be important tools for efficient planning and functioning of FAM.

\section{Author details}

'Department of Acute Admissions (AMA), Odense University Hospital, Denmark. ${ }^{2}$ Board of Directors, Odense University Hospital, Denmark. ${ }^{3}$ Department of Business and Economics, University of Souther Denmark (SDU), Denmark.

Published: 17 September 2010

doi:10.1186/1757-7241-18-S1-P27

Cite this article as: Hansen-Nord et al:: Process driven patient tracks in FAM. Scandinavian Journal of Trauma, Resuscitation and Emergency Medicine 2010 18(Suppl 1):P27.

\section{Submit your next manuscript to BioMed Central and take full advantage of: \\ - Convenient online submission \\ - Thorough peer review \\ - No space constraints or color figure charges \\ - Immediate publication on acceptance \\ - Inclusion in PubMed, CAS, Scopus and Google Scholar \\ - Research which is freely available for redistribution \\ Submit your manuscript at www.biomedcentral.com/submit}

